\title{
Water productivity of maize in the US high plains
}

\author{
Thomas J. Trout ${ }^{1} \cdot$ Kendall C. DeJonge $^{1}$
}

Received: 20 September 2016 / Accepted: 21 March 2017 / Published online: 8 April 2017

(C) The Author(s) 2017. This article is an open access publication

\begin{abstract}
Maize water production functions measured in a 4-year field trial in the US central high plains were curvilinear with $2.0 \mathrm{~kg} \mathrm{~m}^{-3}$ water productivity at full irrigation that resulted from $12.5 \mathrm{Mg} \mathrm{ha}^{-1}$ grain yields with $630 \mathrm{~mm}$ of crop evapotranspiration, ETc. The curvilinear functions show decreasing yield but relatively constant water productivity up to $25 \% \mathrm{ETc}$ reduction. Water productivity declined rapidly with ETc reductions greater than $25 \%$ and was zero at about $40 \%$ of full ETc because about $270 \mathrm{~mm}$ of ETc was required to produce the first unit of grain yield. These results corroborate those of previous studies that show reduction in irrigated area rather than deficit irrigation will usually provide higher net returns if water consumption (ETc) is limited. Water balance techniques adequately estimated ETc when precision irrigation was carefully scheduled and seasonal precipitation was low. Water productivity relationships based on ETc are more transferable than those based on irrigation water applied.
\end{abstract}

\section{Introduction}

Irrigation water supplies in the Great Plains and much of the western US are declining. Supplies originally developed for irrigated agriculture are being diverted to growing urban areas and for ecosystem restoration. Groundwater use in many areas has exceeded sustainable amounts and

Communicated by E. Fereres.

Thomas J. Trout

Thomas.Trout@ars.usda.gov

1 Agricultural Engineers, USDA-ARS Water Management and Systems Research Unit, 2150 Centre Dr, Bldg D, Fort Collins, CO 80526, USA must decrease to prevent aquifer depletion. Temperature increases due to climate change are likely to reduce mountain snowpack accumulation that is critical to irrigation water supplies and may increase watershed evapotranspiration and crop water requirements. Irrigated agriculture will likely have less water available in the future than it had in the past. Sustaining irrigated agriculture and meeting future food and fiber needs of the growing global population will require increasing crop productivity per unit of water.

Past studies have shown that the reduction in yield may be less than the reduction in irrigation water applied-for example, a $30 \%$ reduction in irrigation may result in only a $10 \%$ reduction in yield (Zang 2003). This is because the marginal productivity of irrigation water applied tends to be low when water application is near full irrigation. With deficit irrigation, higher irrigation crop water productivity (ICWP-yield per unit of irrigation water applied) may result from higher efficiency of water applications-less deep percolation, runoff, and evaporation losses from irrigation-and more effective use of precipitation. Higher ICWP with deficit irrigation implies that deficit irrigation may be a way to maximize economic returns per unit irrigation water.

Past studies have also shown that yield relationships based on water consumption or crop evapotranspiration, ETc, are often linear (de Wit 1958; Stewart et al. 1977; Tanner and Sinclair 1983; Sinclair et al. 1984; Hanks 1983; Doorenbos and Kassam 1986; Steduto et al. 2007). This implies that the marginal productivity of the water is constant and deficit irrigation may be no more productive per unit water consumed than irrigation to meet full crop water requirements. In fact, because an amount of water is required to produce the first increment of yield, deficit irrigation will generally have lower crop water productivity (CWP) in terms of consumed water, or ETc, than full 
Table 1 Summary results of recent maize water productivity field trials in the Great Plains

\begin{tabular}{|c|c|c|c|c|c|c|}
\hline References & Location & $\mathrm{ETc}_{\mathrm{M}}(\mathrm{mm})$ & $\begin{array}{l}\text { Yield }_{\mathrm{M}} \\
(\mathrm{Mg} \\
\left.\mathrm{ha}^{-1}\right)\end{array}$ & $\operatorname{ETc}_{\mathrm{I}}(\mathrm{mm})$ & $\begin{array}{l}\mathrm{CWP}_{\mathrm{M}} \\
(\mathrm{Kg} \\
\left.\mathrm{m}^{-3}\right)\end{array}$ & $\mathrm{HI}$ \\
\hline Howell et al. (1989) & Bushland, TX & 840 & 12 & 400 & 1.4 & $0.43-0.55$ \\
\hline $\begin{array}{l}\text { Schneider and Howell } \\
\text { (1998) }\end{array}$ & Bushland, TX & 800 & 14 & 340 & 1.7 & \\
\hline Klocke et al. (2011) & Garden City, KS & 830 & 12 & 200 & 1.5 & $0.51-0.62$ \\
\hline Schlegel et al. (2016) & Tribune, KS & 690 & 14 & 110 & 2.0 & \\
\hline Lamm et al. (2009) & Colby, KS & 660 & 15 & & 2.3 & \\
\hline Payero et al. (2008) & North Platte, NE & 660 & 12 & 260 & 1.8 & $0.53-0.63$ \\
\hline Schneekloth et al. (1991) & North Platte, NE & 670 & 15 & 250 & 2.3 & \\
\hline Djaman et al. (2013) & Clay Center, NE & 630 & 15 & & 2.4 & $0.49-0.57$ \\
\hline Irmak (2015) & Clay Center, NE & 640 & 15 & 280 & 2.3 & \\
\hline Spurgeon and Yonts (2013) & Michell, NE & 530 & 12 & & 2.3 & \\
\hline This study & Greeley, CO & 630 & 13 & 270 & 2.0 & $0.47-0.61$ \\
\hline
\end{tabular}

$E T c_{M}$ maximum measured seasonal crop water use, Yield $_{M}$ grain yield $(15.5 \%$ moisture $)$ at $\mathrm{ETc}_{\mathrm{M}}, E T c_{I}$ projected evapotranspiration required to initiate grain production, $C W P_{M}$ water productivity at $\mathrm{ETc}_{\mathrm{M}}, H I$ harvest index range for all treatments irrigation. If this is the case, where runoff and deep percolation losses can be effectively reused, full irrigation on a reduced irrigated area may provide higher economic returns for the watershed than deficit irrigation. In many Western US watersheds, deep percolation and runoff water is effectively reused, either through downstream rediversion of runoff or recharge of groundwater that is later pumped for beneficial use. For example, in Colorado, reuse of irrigation water return flows is the legal water right of downstream users, so water rights are based on the amount of water consumed rather than the amount of water diverted or applied. Where irrigation water is pumped from groundwater that is replenished with deep percolation, return flows are likewise effectively used, although at somewhat higher cost due to pumping costs and possibly lower water quality.

It is critical to understand the water balance and water law in a watershed to establish the value of water for crop production and the means to maximize water productivity. Improved irrigation efficiency may not produce much "new" water because it results primarily in a reduction of return flows rather than a reduction in ET. Thus, in basins where return flows are effectively reused, deficit irrigation may not be economically beneficial for the basin.

Although many crop water productivity studies have been carried out in the Great Plains (Table 1) and around the world (Stewart et al. 1977; Hanks 1983; Zwart and Bastiannsen 2004), there continues to be a need for better understanding of crop responses to deficit irrigation with the goal to maximize water productivity. In 2008, USDAARS Water Management Research Unit in Fort Collins began a field study of the water productivity of four common Great Plains field crops under a range of irrigation levels from fully irrigated to about $40 \%$ of full irrigation. The objective of this study was to measure the water productivity of a current maize hybrid in the central high plains of the US and to describe the implications of the results on irrigation water management in a water-limited environment. This paper presents results from 2008 to 2011 field trials. The complete dataset from these trials is available from the US Department of Agriculture National Agricultural Library Ag Data Commons: http://dx.doi. org/10.15482/USDA.ADC/1254006 (Trout and Bausch 2017).

\section{Materials and methods}

\section{Experimental site}

The field experiments were carried out at the USDA-Agricultural Research Service limited irrigation research farm (LIRF) located northeast of Greeley, CO $\left(40^{\circ} 26^{\prime} 50^{\prime \prime} \mathrm{N}\right.$, $104^{\circ} 38^{\prime} 10^{\prime \prime} \mathrm{W}$, and 1425 masl). The 16-ha facility was developed to conduct research on irrigated crop water requirements and crop response. The average annual precipitation at the semi-arid site at the western edge of the central High Plains is $350 \mathrm{~mm}$ with $215 \mathrm{~mm}$ between May 1 and Sept 30 (PRISM 2015). Average annual and seasonal precipitation during the 4 years of the study was near normal (340 and $220 \mathrm{~mm}$, respectively). Irrigated maize is the dominant annual crop in the region and county maize grain yields (@15.5\% grain moisture) averaged $11 \mathrm{Mg} \mathrm{ha}^{-1}$ during the 4 years of the experiment (USDA-NASS 2015). 


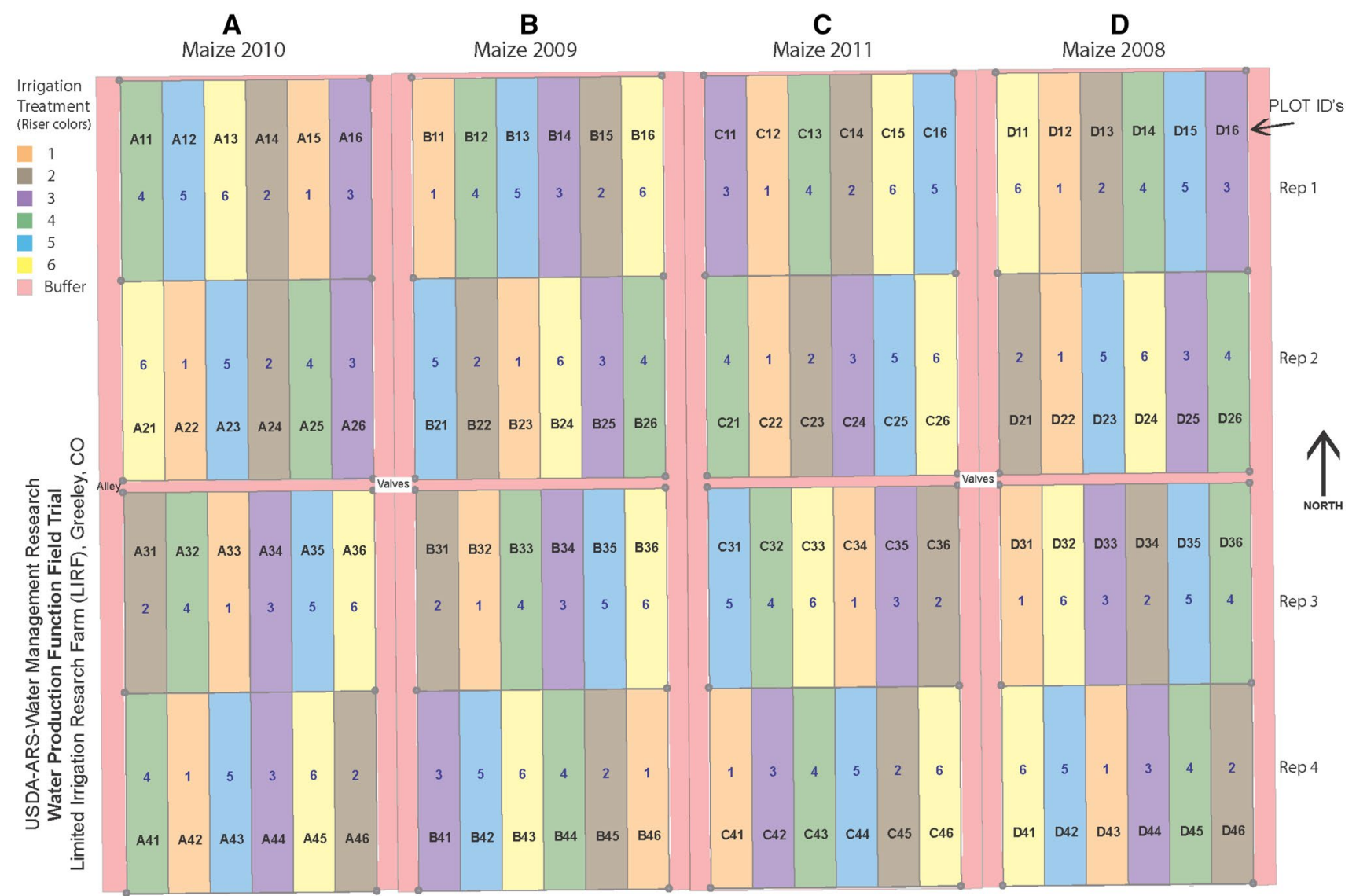

Plot size: Width $9 \mathrm{~m}$ (12 row at $0.76 \mathrm{~m}$ spacing), Length $44 \mathrm{~m}$. Total Area ( $5 \mathrm{ha}) ; 6$ row or $4.5 \mathrm{~m}$ buffers between crops and on field edges 4 Crop rotation: Dry Beans, Winter Wheat, Corn, Sunflower.

Fig. 1 LIRF 2008-2011 field experimental plot layout showing four field sections with the year maize was grown, four replicated blocks, and six randomly assigned treatments

Fig. 2 Aerial view of the water productivity plots at LIRF on August 1, 2008. Crops from left to right are dry beans, winter wheat, sunflower, and maize. Note visible treatment effects in the maize

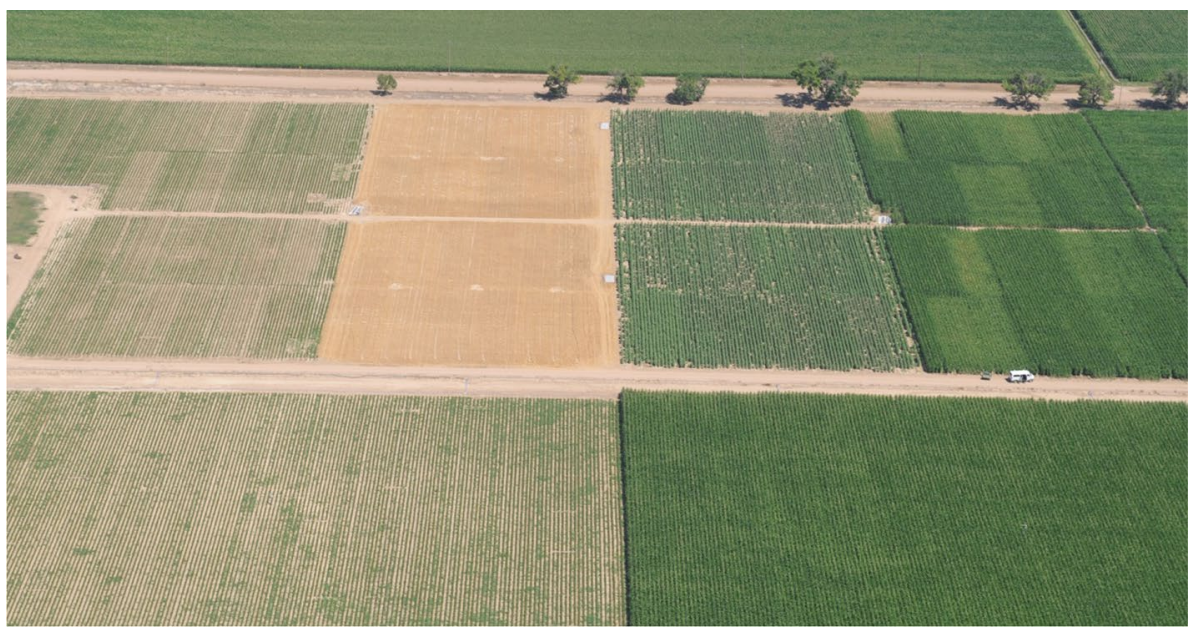

A 4.5-ha experimental field was divided into 4 equal crop sections (Figs. 1, 2). Maize (Zea mays L.) was grown in rotation with sunflower (Helianthus annuus), dry bean (Phaseolus vulgaris), and winter wheat (Triticum aestivum). Maize was grown for 1 year in each section, as shown in Fig. 1, following winter wheat. Each 
field section was divided into four replicate blocks, and each block was divided into six $9 \times 43 \mathrm{~m}$ plots containing $12 \mathrm{~N}-\mathrm{S}$ oriented crop rows ( $0.76 \mathrm{~m}$ row spacing) on which six irrigation treatments were randomly assigned (randomized block design). The east and west edges of each crop section contained a six-row buffer.

The largest portion of the field experimental area contains Olney fine sandy loam soil (fine-loamy, mixed, superactive, mesic Ustic Haplargids). Other soils in the field are Nunn clay loam (fine, smectitic, mesic Aridic Argiustolls) [blocks 3 and 4 of section D (2008 Maize)], and Otero sandy loam (coarse-loamy, mixed, superactive, calcareous, mesic Aridic Ustorthents) [most of section A (2010 Maize)] (USDA-NRCS 2015). The soils classified predominately as sandy loams with some areas and layers of sandy clay loams and loamy sands. The field capacity water content of soil horizons averaged $0.24 \mathrm{~m}^{3} \mathrm{~m}^{-3}$ from 0 to $45 \mathrm{~cm}$ depth, $0.21 \mathrm{~m}^{3} \mathrm{~m}^{-3}$ from 45 to $75 \mathrm{~cm}$ depth, and $0.19 \mathrm{~m}^{3} \mathrm{~m}^{-3}$ from 75 to $105 \mathrm{~cm}$ depth. Total plant available water, TAW, was estimated from pressure plate water release data to be $50 \%$ of field capacity, or about $114 \mathrm{~mm}$ in the $105 \mathrm{~cm}$ root zone depth. Readily available water, RAW, for maize was assumed to be $50 \%$ of TAW, or $25 \%$ of field capacity.

\section{Irrigation treatments}

Six irrigation treatments were randomly assigned to each block. The six treatments were designed to meet portions of full crop water requirements.

$\mathrm{T} 1: 100 \%$ of crop water requirements (no stress)

$\mathrm{T} 2: 85 \%$ of $\mathrm{T} 1$

T3: $75 \%$ of $\mathrm{T} 1$

T4: $70 \%$ of $\mathrm{T} 1$

$\mathrm{T} 5: 55 \%$ of $\mathrm{T} 1$

T6: $40 \%$ of $\mathrm{T} 1$

The full irrigation treatment, T1, was irrigated such that water availability (irrigation plus precipitation plus stored soil water) was adequate to meet crop water requirements. Adequacy was monitored by insuring the soil water content remained in the RAW range. The remaining treatments were irrigated to achieve total water applications (irrigation plus precipitation) that approximated the target treatment amounts.

All treatments were fully irrigated until growth stage V7 (Abendroth et al. 2011) to ensure good crop stands and proper formation of reproductive organs. Water stress treatments were applied from V7 until crop maturity, but stress was temporarily reduced for all treatments during the reproductive growth stages (VT-R2) to ensure adequate pollination and seed initiation. Irrigation was terminated earlier in low water treatments than in the high water treatments.

\section{Crop management}

DeKalb brand 52-59 (VT3) maize seed was planted with a John Deere Maxiplex ${ }^{1}$ planter in early May at 80,000 to 82,000 seeds $\mathrm{ha}^{-1}$. Final plant populations averaged 80,000 plants $\mathrm{ha}^{-1}$ and did not vary by treatment. This 102-day maturity class variety first released in 2006 was a popular variety and maturity class in the region at the time of the study. The variety allowed good herbicide-based weed control (glyphosate resistant) and minimized corn borer and root worm insect damage.

The crop was managed to achieve high yields under fully irrigated conditions. All treatments were planted at the same population and received the same nitrogen applications. Although economically based recommendations may be to reduce plant population and nitrogen application for reduced yield conditions associated with water stress, evidence indicated that, under the experimental conditions, plant population and fertility targeted at high yields would not negatively impact yields under deficit irrigation, so water availability was the only variable among treatments. Minimum tillage (reduced tillage in 2008, no tillage in 2009, and strip tillage in 2010 and 2011) was used to maintain surface residue from the previous wheat crop and minimize surface evaporation.

Nitrogen fertilizer (Urea ammonium nitrate, UAN, $32 \%$ ) was sidedress applied near the seed at planting at $34 \mathrm{~kg} \mathrm{ha}^{-1} \mathrm{~N}$. Additional nitrogen was applied through the irrigation water (fertigation) to meet fertility requirements based on expected yields at full irrigation, pre-plant soil tests for soil nitrogen availability, and nitrogen concentration in the groundwater used for water supply. Note that, due to the high nitrate concentration in the groundwater ( $25 \mathrm{mg} \mathrm{L}{ }^{-1} \mathrm{~N}$ which is equivalent to $0.25 \mathrm{~kg} \mathrm{~N} \mathrm{ha}^{-1} \mathrm{~mm}^{-1}$ of water applied), low water treatments received as much as $50 \mathrm{~kg} \mathrm{ha}^{-1}$ less $\mathrm{N}$ than the high water treatments.

In 2008, 2009, and 2011, a small irrigation was applied following planting to ensure adequate soil water for seed germination and to incorporate herbicide. In 2010, rainfall was adequate for germination and herbicide incorporation. In 2009, a hail event at R1 growth stage damaged leaves and reduced the horizontal canopy structure, and may have reduced yields and ETc.

\footnotetext{
1 The use of trade, firm, or corporation names in this article is for the information and convenience of the reader. Such use does not constitute an official endorsement or approval by the USDA or the Agricultural Research service of any product or service to the exclusion of others that may be suitable.
} 


\section{Irrigation management and water balance measurements}

Weather data from a CoAgMet (Colorado Agricultural Meteorological Network; http://www.coagmet.com) automated weather station (GLY04) located on a 0.4-ha grass lawn adjacent to the research plots were used to calculate ASCE Standardized Penman-Monteith alfalfa reference evapotranspiration (ETr) (ASCE-EWRI 2005). Irrigations were scheduled using FAO-56 dual crop coefficient methodology (Allen et al. 1998) with basal crop coefficients adapted from Table E-2 in Jensen and Allen (2016) and adjusted for measured crop canopy growth and senescence (Allen and Pereira 2009). Precipitation was measured with two recording precipitation gauges located in the experimental field plus a gauge at the weather station.

Irrigations were applied every 4-7 days, depending on the predicted soil water deficits. Irrigation amount for the T1 treatment was based on predicted crop water use and adjusted as needed for measured soil water deficits to maintain the soil water content, SWC, within the RAW range in the active root zone. Irrigations were reduced based on received and anticipated precipitation. Irrigation amounts for the remaining treatments were reduced relative to the T1 treatment to achieve the targeted ETc reductions. If required irrigation amount was less than $12 \mathrm{~mm}$, the irrigation was skipped and the amount was added to the following irrigation.

Irrigation water from a groundwater well was delivered to the corner of each plot through underground PVC pipe and applied through a surface drip irrigation system with thick-walled drip tubing (16 mm outside diameter, $2 \mathrm{~mm}$ wall thickness, $30 \mathrm{~cm}$ in-line emitter spacing, $1.1 \mathrm{~L} \mathrm{~h}^{-1}$ emitter flow rate) placed along each row. The tubing was installed each year after planting and removed before harvest. Irrigation applications to each treatment were measured with turbine flow meters (Badger Recordall Turbo 160 with RTR transmitters). Meters were cross calibrated to ensure accuracy and consistency. Irrigation applications were controlled by and recorded with a Campbell Scientific CR1000 data logger. A constant pressure water supply controlled with a variable speed drive booster pump, low pressure loss in the delivery system, and relatively flat topography resulted in predicted water distribution uniformity among and within plots exceeding 95\%.

Soil water content, SWC, was measured 2 or 3 times each week on the days before and/or after irrigation in the crop row near the center of each plot. Soil water content was measured in $30-\mathrm{cm}$ depth increments between 30 and $150 \mathrm{~cm}$ depth, and at $200 \mathrm{~cm}$ depth with a neutron soil moisture meter, NMM, (CPN-503 Hydroprobe, InstroTek, San Francisco, CA, USA). The SWC in the surface $15 \mathrm{~cm}$ was measured in the row near the NMM access tube with a portable time domain reflectometer (Minitrase, Soilmoisture Equipment Corp, Santa Barbara, CA, USA) with $15-\mathrm{cm}$ long rods. Additional details of the soil water content measurements are given by Trout and Bausch (2017).

Crop evapotranspiration was calculated based on the water balance:

$\Delta S=I+P+\mathrm{UF}-\mathrm{DP}-\mathrm{RO}-\mathrm{ETc}$,

where $\Delta S=$ change (increase) in soil water content in the root zone (average of four replications), $I=$ irrigation application, $P=$ precipitation, $\mathrm{UF}=$ upflux of water from groundwater (assumed 0 because the groundwater table was $>5 \mathrm{~m}$ below the surface), $\mathrm{DP}=$ deep percolation loss of soil water below the root zone, $\mathrm{RO}=$ surface runoff of precipitation or irrigation, and $\mathrm{ETc}=$ crop evapotranspiration, the loss of water to the atmosphere. For the experimental field, RO was assumed zero due to relatively small field slopes, adequate soil infiltration, surface residue, and drip irrigation. Thus, for this study, ETc was estimated as:

$\mathrm{ETc}=I+P-\Delta S-\mathrm{DP}$.

Deep percolation was assumed to occur when precipitation exceeded the soil water deficit $(S W D=$ field capacity minus SWC) in the full root zone at the time of precipitation, and was calculated as the precipitation amount minus soil water deficit measured before the precipitation and minus estimated ETc between the SWC measurement and the precipitation (note that irrigation never exceeded SWD and thus caused no DP). An increase in SWC below the root zone following precipitation provided confirmation of DP. Due to the semi-arid climate and careful irrigation scheduling, deep percolation losses occurred only in 2008 following a large precipitation event. Root zone depth was taken to be $105 \mathrm{~mm}$ because there was no evidence of water uptake from deeper depths. Thus soil water storage was calculated from the SWC measurements at the $0-15,30,60$, and $90 \mathrm{~cm}$ depths and converted to equivalent water depths.

Surface evaporation was estimated for the field conditions by assuming that the total evaporable water, TEW (Allen et al. 1998), was $12 \mathrm{~mm}$ and that evaporation occurred only from the wetted sunlit soil surface between each wetting event. For consistency, seasonal crop ETc was calculated for 172 days beginning at planting in early May and ending in late October after the maize was fully senesced and ready for harvest (grain moisture content $<17 \%$ ).

\section{Plant measurements}

Above ground biomass was measured before harvest. Ten or fifteen complete corn plants from each plot were cut $2 \mathrm{~cm}$ above the soil surface, ears were removed, and the remaining stover dried in an oven at $60^{\circ} \mathrm{C}$ for $48 \mathrm{~h}$ and 
Table 2 Maize crop log for the $\mathrm{T} 1$ treatments including planting day of year (DOY) and elapsed days (DAP) and growing degree days (GDD, $30^{\circ} \mathrm{C}$ maximum, $10^{\circ} \mathrm{C}$ base between planting and critical growth stages

\begin{tabular}{|c|c|c|c|c|c|c|c|c|}
\hline \multirow{3}{*}{$\begin{array}{l}\text { Year } \\
\text { Planting (DOY) } \\
\text { Growth stage, event }\end{array}$} & \multicolumn{2}{|l|}{2008} & \multicolumn{2}{|l|}{2009} & \multicolumn{2}{|l|}{2010} & \multicolumn{2}{|l|}{2011} \\
\hline & \multicolumn{2}{|l|}{133} & \multicolumn{2}{|l|}{131} & \multicolumn{2}{|l|}{131} & \multicolumn{2}{|l|}{123} \\
\hline & DAP & GDD & DAP & GDD & DAP & GDD & DAP & GDD \\
\hline Emergence & 20 & 155 & 11 & 91 & 13 & 68 & $22^{\mathrm{a}}$ & 100 \\
\hline V7 & 51 & 440 & 45 & 337 & 48 & 396 & 56 & 399 \\
\hline VT/R1 & 86 & 847 & 84 & 745 & 83 & 792 & 90 & 819 \\
\hline R4 & 120 & 1128 & 117 & 1067 & $116^{\mathrm{a}}$ & 1145 & 120 & 1171 \\
\hline R6 & 155 & 1346 & $143^{\mathrm{a}}$ & 1247 & $141^{\mathrm{a}}$ & 1368 & $142^{\mathrm{a}}$ & 1341 \\
\hline Senescence & $155^{\mathrm{b}}$ & 1346 & $145^{\mathrm{b}}$ & 1254 & $145^{\mathrm{a}}$ & 1398 & 154 & 1454 \\
\hline Harvest & 178 & 1446 & 185 & 1353 & 161 & 1490 & 175 & 1556 \\
\hline
\end{tabular}

${ }^{\mathrm{a}}$ Estimated DAP and GDD

${ }^{\mathrm{b}}$ Killing frost weighed. Ears were likewise dried, grain was removed from the cobs, and both components redried and then weighed. Above ground biomass included stover, cobs, and grain. Plot above ground biomass was calculated as the total mass per plant (kg per plant) multiplied by the plot plant population (plants $\mathrm{m}^{-2}$ ). Harvest Index was calculated as the ratio of dry grain mass to total above ground dry biomass. Average kernel mass was measured on 1000 dry grains.

Grain yield was measured by hand harvesting the ears from the center $15 \mathrm{~m}$ of the center four rows of each plot $\left(46 \mathrm{~m}^{2}\right)$. In 2011 , yield sample area was increased to $23 \mathrm{~m}$ length $\left(70 \mathrm{~m}^{2}\right)$. Grain was threshed with a stationary thresher (Wintersteiger Classic ST, Wintersteiger AG, Ried, Austria), weighed and subsampled for moisture content determination. Grain moisture content at harvest was measured with a Dickey-john GAC500-XT Moisture Tester (Dickey-john Corp, Aubern, Ill). Yield $\left(\mathrm{kg} \mathrm{ha}^{-1}\right)$ was normalized to $15.5 \%$ moisture content (commercial yield standard).

Additional detail of methodology used in this trial is given by Trout and Bausch (2017).

\section{Results}

Table 2 gives the planting dates and elapsed days after planting (DAP) and growing degree days since planting (GDD) for critical growth stages for the T1 treatment. Stage V7 designates 7 leaves, VT designates tassel emergence and the beginning of reproductive growth stage which was always within 3 days of silk emergence (R1), R4 designates the end of milk stage and beginning of grain maturation, and R6 designates grain black layer and physiological maturity (Abendroth et al. 2011). Growth stages up to R4 for other treatments typically varied from these values by no more than 3 days. The senescence date (no remaining green leaves) varied among treatments except when the crop was killed by frost and, in general, was accelerated by stress. The 102-day maturity class variety required an average of 800 GDD to reach tassel formation (VT) and 1325 GDD from planting to physiological maturity (R6).

Table 3 presents the water balance components for each treatment for each year. Seasonal precipitation (planting to 172 days after planting) varied from 201 to $251 \mathrm{~mm}$, which is close to the long-term average. Alfalfa reference evapotranspiration during this period was $983,880,976$, and $1034 \mathrm{~mm}$ for 2008-2011, respectively, and averaged $970 \mathrm{~mm}$

Average irrigation amounts varied from $427 \mathrm{~mm}$ for the $\mathrm{T} 1$ treatment to $126 \mathrm{~mm}$ for the T6 treatment. Irrigation amount was decreased by $70 \%$ for the $\mathrm{T} 6$ treatment in order to achieve the average ETc reduction of $40 \%$. This was because all treatments received the same amount of precipitation, deficit irrigation treatments used more stored soil water, and, in 2008, the well-watered treatments lost more water to deep percolation.

The only year with estimated deep percolation was 2008 as a result of a large mid-season precipitation event $(95 \mathrm{~mm}$ in 3 days). In 2008, estimated deep percolation varied from $80 \mathrm{~mm}$ in T1 to $0 \mathrm{~mm}$ in T6. Soil water storage always declined between planting and maturity with T6, and generally declined with all stress treatments. In 2011, late season precipitation resulted in increased seasonal soil water storage except in treatment T6. Only with the T6 treatment did storage contribute $10 \%$ or more of ETc. Thus, with careful irrigation scheduling in this study, irrigation plus precipitation accounted for more than $90 \%$ of water balance calculated ETc. Because precipitation and irrigation were measured accurately, potential error in seasonal ETc calculations was small.

Seasonal crop evapotranspiration of the T1 treatment ranged from 616 to $648 \mathrm{~mm}$, and averaged $633 \mathrm{~mm}$ which was $65 \%$ of seasonal ETr. About one-third of T1 ETc was provided by in-season precipitation. Soil water 
Table 3 Seasonal water balance components for the LIRF 2008-2011 water productivity study

\begin{tabular}{|c|c|c|c|c|c|c|c|c|}
\hline Year & Precip (mm) & Tmnt & Irrigation (mm) & $\Delta \mathrm{S}(\mathrm{mm})$ & $\begin{array}{l}\text { Deep } \\
\text { Perc } \\
(\mathrm{mm})\end{array}$ & $\operatorname{ETc}(\mathrm{mm})$ & Evap (mm) & Trans (mm) \\
\hline \multirow[t]{6}{*}{2008} & \multirow[t]{6}{*}{251} & $\mathrm{~T} 1$ & 438 & -25 & 80 & 635 & 58 & 560 \\
\hline & & $\mathrm{T} 2$ & 338 & -7 & 38 & 559 & 58 & 486 \\
\hline & & $\mathrm{T} 3$ & 282 & -20 & 16 & 538 & 57 & 466 \\
\hline & & $\mathrm{T} 4$ & 271 & -23 & 30 & 516 & 58 & 444 \\
\hline & & $\mathrm{T} 5$ & 180 & -35 & 22 & 445 & 62 & 373 \\
\hline & & T6 & 137 & -43 & 0 & 431 & 63 & 356 \\
\hline \multirow[t]{6}{*}{2009} & \multirow[t]{6}{*}{231} & $\mathrm{~T} 1$ & 418 & 16 & 0 & 634 & 82 & 537 \\
\hline & & $\mathrm{T} 2$ & 346 & 0 & 0 & 578 & 82 & 483 \\
\hline & & $\mathrm{T} 3$ & 299 & -11 & 0 & 542 & 83 & 445 \\
\hline & & $\mathrm{T} 4$ & 244 & -17 & 0 & 493 & 82 & 399 \\
\hline & & $\mathrm{T} 5$ & 168 & -30 & 0 & 429 & 92 & 327 \\
\hline & & T6 & 110 & -38 & 0 & 379 & 94 & 278 \\
\hline \multirow[t]{6}{*}{2010} & \multirow[t]{6}{*}{212} & $\mathrm{~T} 1$ & 366 & -38 & 0 & 616 & 66 & 535 \\
\hline & & $\mathrm{T} 2$ & 303 & -44 & 0 & 559 & 64 & 482 \\
\hline & & $\mathrm{T} 3$ & 252 & -41 & 0 & 506 & 63 & 428 \\
\hline & & $\mathrm{T} 4$ & 219 & -29 & 0 & 461 & 61 & 386 \\
\hline & & $\mathrm{T} 5$ & 153 & -28 & 0 & 393 & 67 & 311 \\
\hline & & T6 & 100 & -42 & 0 & 355 & 68 & 272 \\
\hline \multirow[t]{6}{*}{2011} & \multirow[t]{6}{*}{201} & $\mathrm{~T} 1$ & 485 & 38 & 0 & 648 & 79 & 531 \\
\hline & & $\mathrm{T} 2$ & 388 & 22 & 0 & 567 & 78 & 461 \\
\hline & & T3 & 328 & 6 & 0 & 524 & 79 & 421 \\
\hline & & $\mathrm{T} 4$ & 306 & 1 & 0 & 507 & 80 & 407 \\
\hline & & T5 & 222 & 0 & 0 & 422 & 88 & 313 \\
\hline & & T6 & 157 & -10 & 0 & 368 & 94 & 254 \\
\hline
\end{tabular}

Precip seasonal precipitation, $\Delta S$ change in soil water storage from planting to end of season, Deep Perc deep percolation loss of water below the root zone, ETc crop evapotranspiration, Evap estimated evaporation from wet soil, Trans estimated crop transpiration (ETc-Evap) between emergence and maturity (R6). All components except transpiration were cumulative between planting to 172 days after planting measurements indicated no soil water stress in the T1 treatment (the soil water deficit never exceeded plant readily available water, RAW) except in 2010 when irrigation was inadvertently terminated early and large deficits occurred late in the season (after R3 growth stage) and for two 3-day periods in mid-season. This is the reason for the relatively low T1 ETc in 2010.

Due to the decision to fully irrigate all treatments until growth stage V7 and to temporarily relieve stress at flowering, uptake from soil water storage in the deficit-irrigated treatments, and unanticipated precipitation; actual average seasonal ETc of the deficit-irrigated treatments exceeded the treatment targets. The average ETc of the treatments relative to T1 were: $89,83,78,67$, and $60 \%$ for treatments T2-T6, respectively.

Although soil evaporation is difficult to measure in a growing crop, estimates are useful to allow estimation of plant transpiration, which is physiologically related to yield. The wet soil evaporation component of ETc was estimated to vary between 58 and $94 \mathrm{~mm}$ and averaged $73 \mathrm{~mm}$.
This amounts to about $12 \%$ of T1 ETc and $20 \%$ of T6 ETc. Estimated soil evaporation did not increase with increased irrigation amount, even though numbers of irrigations and irrigation amounts were higher, because of the in-row drip irrigation and treatments that received more irrigation water also had earlier and greater ground shading from a larger canopy. Evaporation estimated by this methodology tended to decrease slightly with increased irrigation.

Figure 3 shows the soil water deficits $(\mathrm{SWD}=$ field capacity-SWC) through the season for the six treatments in 2011. The lines represent predicted SWD from the FAO56 two-step dual crop coefficient model and the data points represent measured soil water deficits in the active root zone. The basal crop coefficients used in the modeled SWD were adjusted so that the model would closely match the measurements. The graphs show how deficits in the stress treatments increased after V7 (DOY 150), stayed relatively constant near VT (DOY 213) when extra irrigation water was applied to all deficit treatments, and then increased to the end of the year. The dashed line represents the RAW 


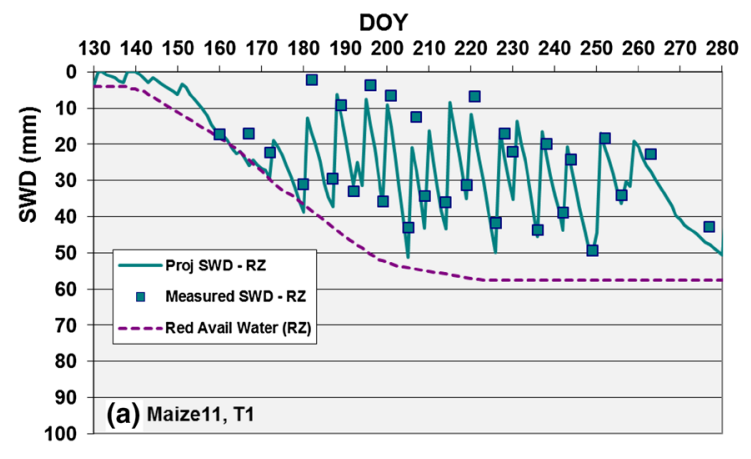

DOY
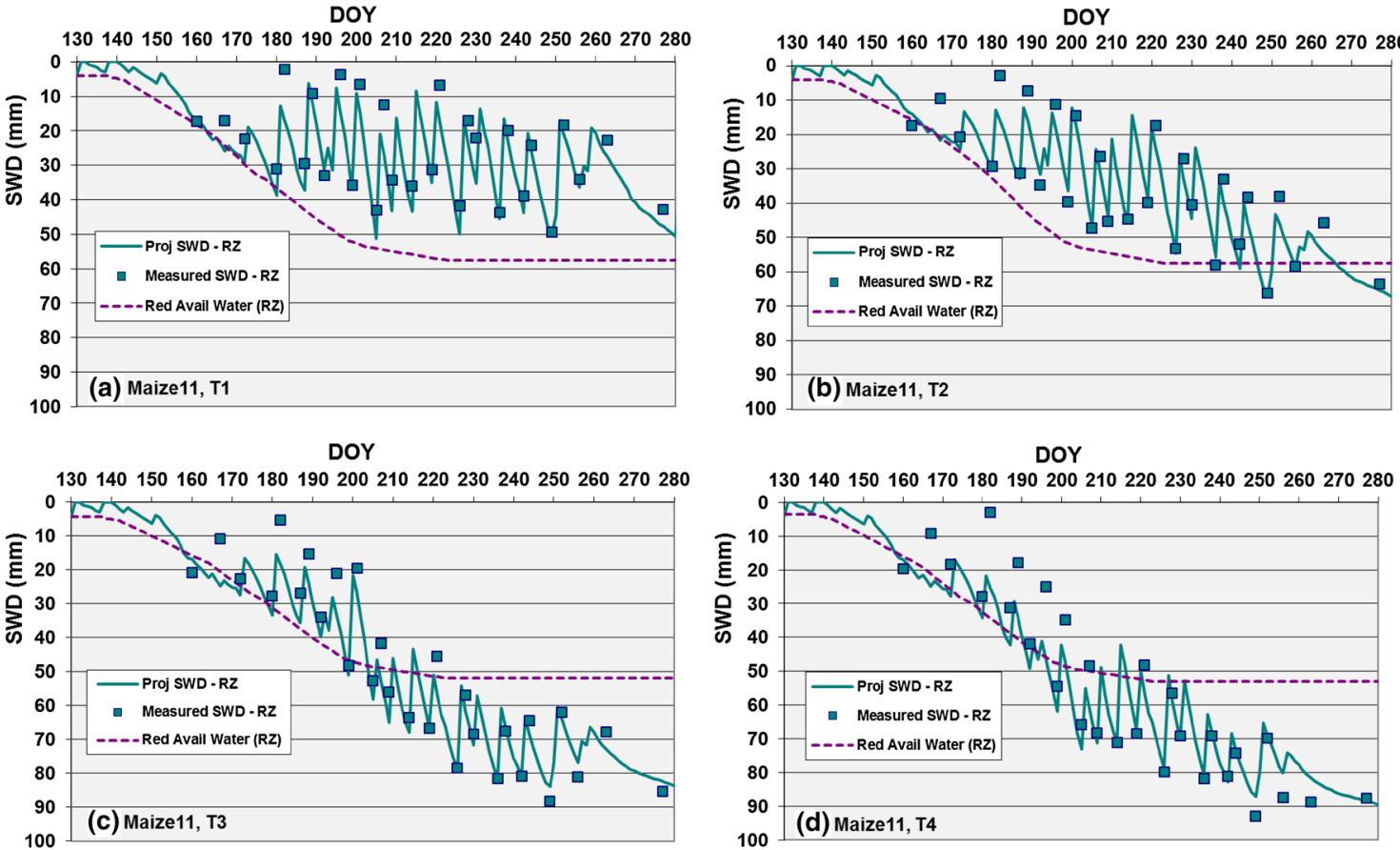

DOY

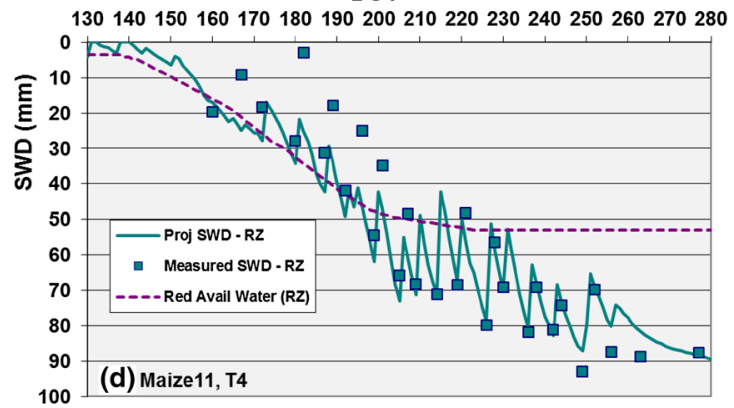

DOY

130140150160170180190200210220230240250260270280
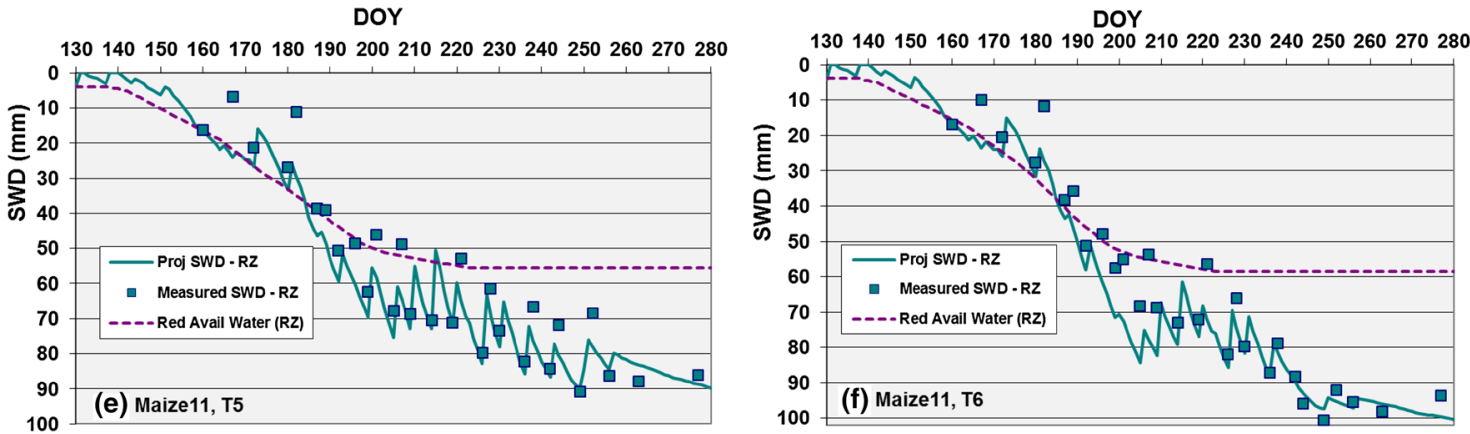

Fig. 3 Maize 2011 soil water deficit (SWD, mm) for treatments T1-T6. Squares are the measured SWD in the active root zone, solid line is the modeled SWD, and the dashed line represents the readily available water (RAW) for the active root zone

(25\% of the field capacity) which increases as the root zone expands. Note that the estimated RAW varied slightly among treatments due to the plot variations in soil field capacity. Treatment $\mathrm{T} 1$ deficits generally remain less than RAW, T2 exceeds RAW only at the end of the season, and the remaining treatments exceed RAW for much of the season. Final deficits reached $100 \mathrm{~mm}$ in T5 and T6, which is close to assumed average TAW of $50 \%$ of field capacity or about $115 \mathrm{~mm}$.

A soil water deficit-based stress coefficient, Ks, was calculated as (Allen et al. 1998):

$K \mathrm{~s}=(\mathrm{TAW}-\mathrm{SWD}) /(\mathrm{TAW}-\mathrm{RAW})$.

By this model, $K \mathrm{~s}$ is 1.0 for $\mathrm{SWD} \leq \mathrm{RAW}$, and decreases linearly to 0.0 when SWD=TAW. Table 4 shows average seasonal stress for each year and treatment over approximately 130 days between plant emergence and physiological maturity. High values indicate low seasonal stress. This parameter shows the increasing stress with decreasing irrigation applications and annual variations in stress levels; and that $\mathrm{T} 1$ and $\mathrm{T} 2$ experienced no days when SWD > RAW in 2008, 2009, and 2011.

Growth stages in which most days had moderate $(0.75>K \mathrm{~s}>0.50)$ or severe $(K \mathrm{~s}<0.5)$ stress are also shown in Table 4 . Note that stages V1-V17 are vegetative stages, VT represents initiation of flowering (tassel emergence), R1-R3 are the grain pollination and formation stages, and R4-R6 represent grain fill and maturation stages. Past studies have shown that maize grain yield is most sensitive to water stress before V7 and from VT-R3 (Cakir 2004; Salter and Goode 1967). Table 4 shows that in all years and treatments, stress did not reach the moderate level before V8, and only in T5 and T6 did stress reach the moderate level during VT-R2 or the severe 
Table 4 Water stress amounts and periods for the LIRF 2008-2011 water productivity study

\begin{tabular}{|c|c|c|c|c|}
\hline Year & Treatment & Seasonal Stress & Moderate stress growth stages & Severe stress growth stages \\
\hline \multirow[t]{6}{*}{2008} & $\mathrm{~T} 1$ & 1.00 & & \\
\hline & $\mathrm{T} 2$ & 1.00 & & \\
\hline & $\mathrm{T} 3$ & 0.98 & & \\
\hline & $\mathrm{T} 4$ & 0.95 & & \\
\hline & T5 & 0.84 & V10-V16, R4 & R5-R6 \\
\hline & T6 & 0.84 & V10-V16, R4 & R5-R5 \\
\hline \multirow[t]{6}{*}{2009} & $\mathrm{~T} 1$ & 1.00 & & \\
\hline & $\mathrm{T} 2$ & 1.00 & & \\
\hline & $\mathrm{T} 3$ & 0.99 & & \\
\hline & $\mathrm{T} 4$ & 0.94 & V11-V12 & \\
\hline & $\mathrm{T} 5$ & 0.77 & V10-VT, R1-R2 & R3-R6 \\
\hline & T6 & 0.70 & V10-VT, R1-R2 & V11-V12, R3-R6 \\
\hline \multirow[t]{6}{*}{2010} & $\mathrm{~T} 1$ & 0.79 & & R5-R6 \\
\hline & $\mathrm{T} 2$ & 0.77 & V17-VT, R4 & R5-R6 \\
\hline & $\mathrm{T} 3$ & 0.71 & V17-VT, R4 & R5-R6 \\
\hline & $\mathrm{T} 4$ & 0.70 & V11-VT & R4-R6 \\
\hline & $\mathrm{T} 5$ & 0.57 & V8-V10 & V11-VT, R3-R6 \\
\hline & T6 & 0.54 & V8-V14 & V14-VT, R3-R6 \\
\hline \multirow[t]{6}{*}{2011} & $\mathrm{~T} 1$ & 1.00 & & \\
\hline & $\mathrm{T} 2$ & 1.00 & & \\
\hline & $\mathrm{T} 3$ & 0.85 & R3-R6 & \\
\hline & $\mathrm{T} 4$ & 0.83 & V15-VT, R3-R6 & \\
\hline & $\mathrm{T} 5$ & 0.82 & V10-V16, R1-R4 & R5-R6 \\
\hline & $\mathrm{T} 6$ & 0.77 & V12-VT, R2-R3 & R4-R6 \\
\hline
\end{tabular}

$K$ s is a stress coefficient based on soil water deficit as defined by Eq. 3. Seasonal stress is the average of daily $K$ s over approximately 130 days between maize emergence and maturity $(1.0=$ no stress $)$. Moderate stress growth stages are the growth stages during which $0.75>K \mathrm{~s}>0.5$ for most days. Severe stress growth stages are the growth stages in which $K \mathrm{~s}<0.5$ for most days

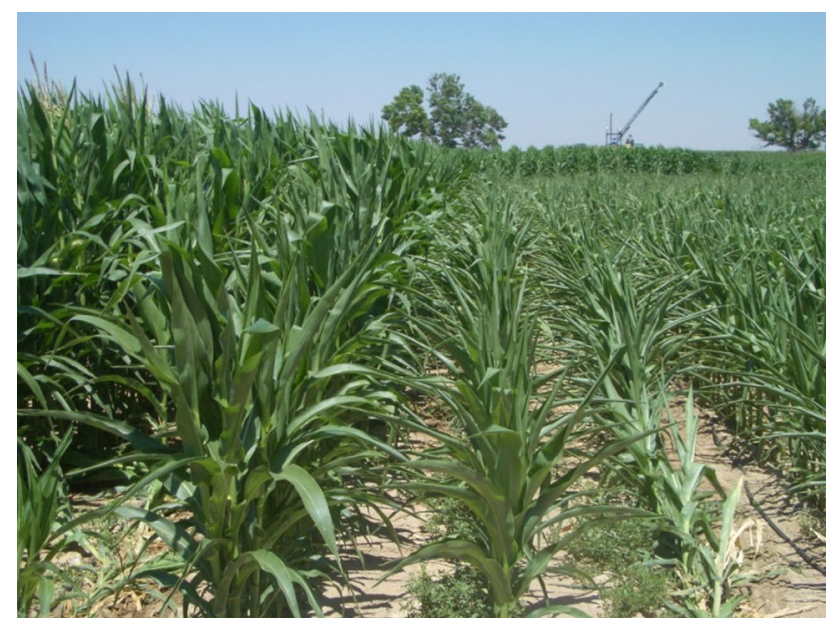

Fig. 4 Comparison of maize growth and condition on Aug 4, 2008 just before tasseling (VT). Rows at the left and background are fully irrigated (T1); rows at right are the lowest irrigation level (T6) level in R3. In 2008, a large precipitation event at R1 refilled the soil water holding capacity and relieved stress in all treatments until late in the season. In 2010, early termination of irrigation in all treatments resulted in severe stress in all treatments during late growth stages.

Figures 4 and 5 illustrate the response of the maize crops to the water stress. The side-by-side photos of $\mathrm{T} 1$ and $\mathrm{T} 6$ crops show that the water stress greatly reduced both the height of the crop and the canopy ground cover. Table 5 gives crop canopy cover and height data for the treatments. The average maximum crop height was 243 , 232, 231, 200, 159, and $147 \mathrm{~cm}$ for the T1 through T6 treatments, respectively. The maximum canopy cover exceeded $90 \%$ for $\mathrm{T} 1-\mathrm{T} 3$ each year, averaged $89 \%$ for $\mathrm{T} 4$, but never reached effective full cover for T5 (78\%) and T6 (72\%). Canopy ground cover of crops under stress fluctuated diurnally due to leaf curl in the afternoons when evaporative demand was high so ground cover measurements were made prior to peak evaporative demand to reduce leaf curl impacts (Trout and Bausch 2017). 
Fig. 5 Overhead photos showing maize canopy on Aug 1, 2008. Left photo is well-irrigated (T1), right is stressed (T6)

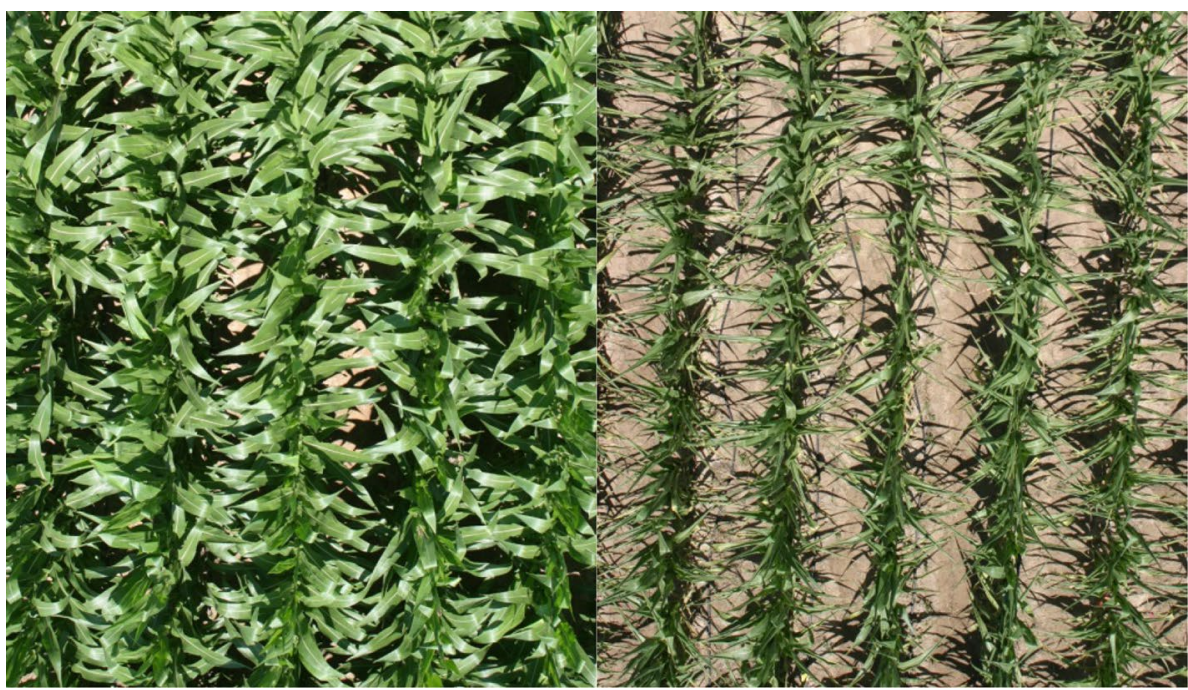

\begin{tabular}{|c|c|c|c|c|c|c|c|c|}
\hline Year & Tmnt & Max cover $(\%)$ & $\begin{array}{l}\text { Full } \\
\text { cover } \\
\text { (DOY) }\end{array}$ & $\begin{array}{l}\text { Max crop } \\
\text { Ht. }(\mathrm{cm})\end{array}$ & $\begin{array}{l}\text { Final bio- } \\
\text { mass }(\mathrm{Mg} \\
\left.\mathrm{ha}^{-1}\right)\end{array}$ & HI & $\begin{array}{l}\text { Kernel mass } \\
\left(\mathrm{g} \mathrm{seed}^{-1}\right)\end{array}$ & $\begin{array}{l}\text { Grain } \\
\text { yield } \\
\left(\mathrm{Mg} \mathrm{ha}^{-1}\right)\end{array}$ \\
\hline \multirow[t]{6}{*}{2008} & $\mathrm{~T} 1$ & 90 & 200 & $220 \mathrm{a}$ & $21.47 \mathrm{a}$ & $0.57 b$ & $0.293 \mathrm{ab}$ & $13.23 \mathrm{a}$ \\
\hline & $\mathrm{T} 2$ & 90 & 203 & $210 \mathrm{ab}$ & $20.95 a$ & $0.57 \mathrm{~b}$ & $0.296 \mathrm{a}$ & $12.94 \mathrm{a}$ \\
\hline & $\mathrm{T} 3$ & 90 & 207 & $191 b$ & $19.44 \mathrm{ab}$ & $0.58 \mathrm{ab}$ & $0.296 \mathrm{a}$ & $12.60 \mathrm{a}$ \\
\hline & $\mathrm{T} 4$ & 90 & 211 & $164 \mathrm{c}$ & $17.44 \mathrm{~b}$ & $0.61 \mathrm{a}$ & $0.289 \mathrm{abc}$ & $11.35 \mathrm{~b}$ \\
\hline & T5 & 83 & 225 & $125 d$ & $13.74 \mathrm{c}$ & $0.61 \mathrm{ab}$ & $0.274 \mathrm{c}$ & $9.01 \mathrm{c}$ \\
\hline & $\mathrm{T} 6$ & 83 & 240 & $116 \mathrm{~d}$ & $13.89 \mathrm{c}$ & $0.60 \mathrm{ab}$ & $0.278 b c$ & $8.82 \mathrm{c}$ \\
\hline \multirow[t]{6}{*}{2009} & $\mathrm{~T} 1$ & 92 & 194 & $246 \mathrm{a}$ & $20.60 \mathrm{a}$ & $0.56 \mathrm{ab}$ & $0.252 \mathrm{a}$ & $12.10 \mathrm{a}$ \\
\hline & $\mathrm{T} 2$ & 92 & 194 & $231 \mathrm{ab}$ & $21.27 \mathrm{a}$ & $0.57 \mathrm{ab}$ & $0.253 \mathrm{a}$ & $11.59 \mathrm{a}$ \\
\hline & $\mathrm{T} 3$ & 92 & 194 & $230 \mathrm{ab}$ & $19.12 \mathrm{ab}$ & $0.58 \mathrm{a}$ & $0.247 \mathrm{a}$ & $11.02 \mathrm{a}$ \\
\hline & $\mathrm{T} 4$ & 90 & 200 & $218 b$ & $17.88 \mathrm{~b}$ & $0.58 \mathrm{a}$ & $0.247 \mathrm{a}$ & $10.32 \mathrm{a}$ \\
\hline & $\mathrm{T} 5$ & 79 & $\mathrm{n} / \mathrm{a}$ & $170 \mathrm{c}$ & $14.17 \mathrm{c}$ & $0.59 \mathrm{a}$ & $0.224 b$ & $8.04 b$ \\
\hline & $\mathrm{T} 6$ & 73 & $\mathrm{n} / \mathrm{a}$ & $164 c$ & $11.05 \mathrm{~d}$ & $0.54 b$ & $0.205 \mathrm{c}$ & $5.94 \mathrm{c}$ \\
\hline \multirow[t]{6}{*}{2010} & $\mathrm{~T} 1$ & 90 & 191 & $228 \mathrm{a}$ & $18.31 \mathrm{a}$ & $0.59 \mathrm{a}$ & $\mathrm{n} / \mathrm{a}$ & $11.17 \mathrm{ab}$ \\
\hline & $\mathrm{T} 2$ & 90 & 191 & $223 \mathrm{a}$ & $18.16 \mathrm{a}$ & $0.59 \mathrm{a}$ & $\mathrm{n} / \mathrm{a}$ & $11.44 \mathrm{a}$ \\
\hline & $\mathrm{T} 3$ & 90 & 191 & $210 \mathrm{a}$ & $15.78 \mathrm{ab}$ & $0.59 \mathrm{ab}$ & $\mathrm{n} / \mathrm{a}$ & $10.46 \mathrm{ab}$ \\
\hline & $\mathrm{T} 4$ & 88 & 191 & $182 b$ & $14.71 \mathrm{~b}$ & $0.59 \mathrm{ab}$ & $\mathrm{n} / \mathrm{a}$ & $9.32 b$ \\
\hline & $\mathrm{T} 5$ & 75 & $\mathrm{n} / \mathrm{a}$ & $157 \mathrm{c}$ & $11.17 \mathrm{c}$ & $0.60 \mathrm{a}$ & $\mathrm{n} / \mathrm{a}$ & $7.15 \mathrm{c}$ \\
\hline & T6 & 66 & $\mathrm{n} / \mathrm{a}$ & $142 \mathrm{c}$ & $9.03 \mathrm{c}$ & $0.56 b$ & $\mathrm{n} / \mathrm{a}$ & $5.50 \mathrm{c}$ \\
\hline \multirow[t]{6}{*}{2011} & $\mathrm{~T} 1$ & 90 & 196 & $276 a$ & $21.92 \mathrm{a}$ & $0.56 \mathrm{a}$ & $0.262 \mathrm{a}$ & $13.64 \mathrm{a}$ \\
\hline & $\mathrm{T} 2$ & 90 & 198 & $263 a b$ & $19.77 \mathrm{a}$ & $0.56 \mathrm{a}$ & $0.253 \mathrm{ab}$ & $12.50 \mathrm{a}$ \\
\hline & $\mathrm{T} 3$ & 90 & 202 & $248 a b$ & $17.34 \mathrm{~b}$ & $0.56 \mathrm{a}$ & $0.234 \mathrm{ab}$ & $10.37 \mathrm{~b}$ \\
\hline & $\mathrm{T} 4$ & 87 & 203 & $235 b$ & $17.13 \mathrm{~b}$ & $0.55 \mathrm{a}$ & $0.232 b c$ & $10.29 b$ \\
\hline & $\mathrm{T} 5$ & 75 & $\mathrm{n} / \mathrm{a}$ & $185 \mathrm{c}$ & $11.95 \mathrm{c}$ & $0.54 \mathrm{a}$ & $0.204 \mathrm{c}$ & $7.23 \mathrm{c}$ \\
\hline & T6 & 65 & $\mathrm{n} / \mathrm{a}$ & $166 c$ & $9.99 \mathrm{c}$ & $0.47 b$ & $0.169 \mathrm{~d}$ & $3.97 \mathrm{~d}$ \\
\hline
\end{tabular}

Max cover maximum canopy ground cover, Full cover day of year when crop reached $80 \%$ canopy ground cover ( $n / a$ crop did not reach $80 \%$ cover), Max Crop Ht. maximum canopy height (without tassel), Final Biomass total above ground biomass (oven dry), HI harvest index (dry grain mass divided by total above ground dry biomass), Kernel Mass final average dry mass per kernel, Grain Yield grain yield at 15.5\% moisture content. Treatment means followed the same letter in a column in a year are not significantly different $(p<0.05)$ 


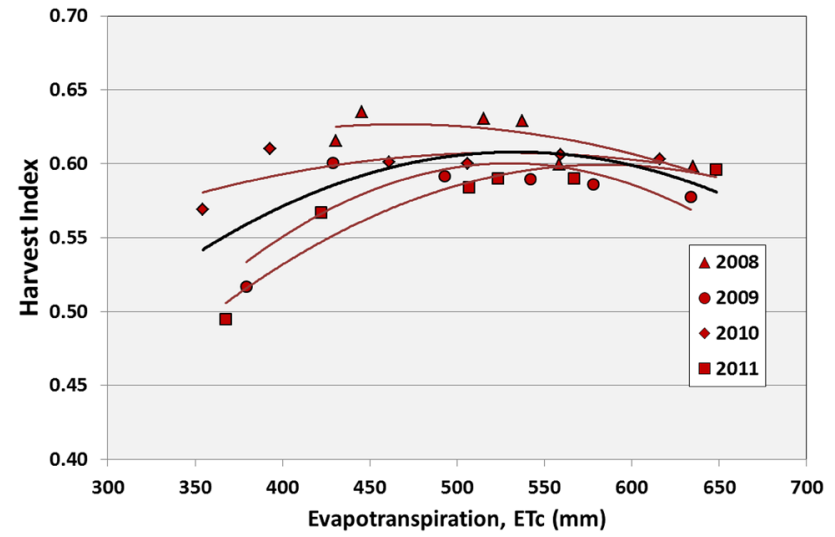

Fig. 6 LIRF 2008-2011 Maize harvest index vs crop evapotranspiration, ETc. Narrow (colored) lines are 2nd degree polynomial curve fit to each year's data; the thick line (black) is a 2nd degree polynomial fit to the combined data

Table 5 lists the mean crop growth and yield responses each year for each treatment. Reduced irrigation and ETc decreased maximum crop height, average final kernel mass, final above ground biomass, and grain yield. In most years, the mean biomass and grain yields decrease with each decrement of ETc although $\mathrm{T} 1$ and $\mathrm{T} 2$ yields are not significantly different. In all years, T5 and T6 had significantly lower biomass and grain yield than the other treatments. T1 and T2 yields tended to be lower in 2009 due to hail just before tasseling that damaged leaves and likely reduced light interception and photosynthesis; and in 2010 due to lack of late season irrigation and resulting stress. The mean grain yield of $\mathrm{T} 1$ for the 4 years was $12.5 \mathrm{Mg} \mathrm{ha}^{-1}$ which exceeded the average county irrigated maize yield by about 15\% (USDA-NASS 2015).
Table 5 also lists the harvest index (portion of above total ground biomass that is grain) for each treatment. Harvest index, HI, varied between 0.47 and 0.61 . The general lack of a large variation in $\mathrm{HI}$ may result from the irrigation management in which there was no stress during germination and early growth when critical reproductive organs are formed, and stress was partially relieved during the sensitive pollination and grain formation stages. Although the impact of water stress on harvest index in this study was small, the highest HI values generally occurred at intermediate treatment levels and the HI vs ETc relationships tend to be concave downward as shown in Fig. 6. It appears that a moderate amount of stress during vegetative stages reduces the size of the above ground vegetation more than it reduces the plant's capacity to product grain. Reduced $\mathrm{HI}$ with stress is expected if the reproductive stage stress reduces pollination and grain formation, or maturation stage stress reduces grain fill. At some high stress level, the plant would not be able to produce grain and HI would be zero.

Figure 7 plots mean grain yield for each treatment vs irrigation water applied and ETc. The curves shown represent a 2 nd degree polynomial fit (least squares regression) to each set of annual data. The right set of curves represent water production functions, WPF, for the relationship between yield and ETc. In all years, the data indicated a concave downward curvilinear relationship. The thick black lines and equations represent the best fit to the four years of combined data. A mixed model statistical analysis of all years of yield data from each plot indicated that the squared term, and thus the curvilinearity, is highly significant $(p<0.0001)$. The slopes of these curves show that less production is lost per amount of ETc decrease with small water
Fig. 7 LIRF 2008-2011 Maize grain yield (@15.5\% moisture content) vs. irrigation water applied (left curves, blue symbols) and crop evapotranspiration (right curves, red symbols). Narrow (colored) lines are 2nd degree polynomial regression fits to the mean yield data for each year. Thick (black) lines and equations are 2 nd degree polynomial regression fits to the combined 4 years of data

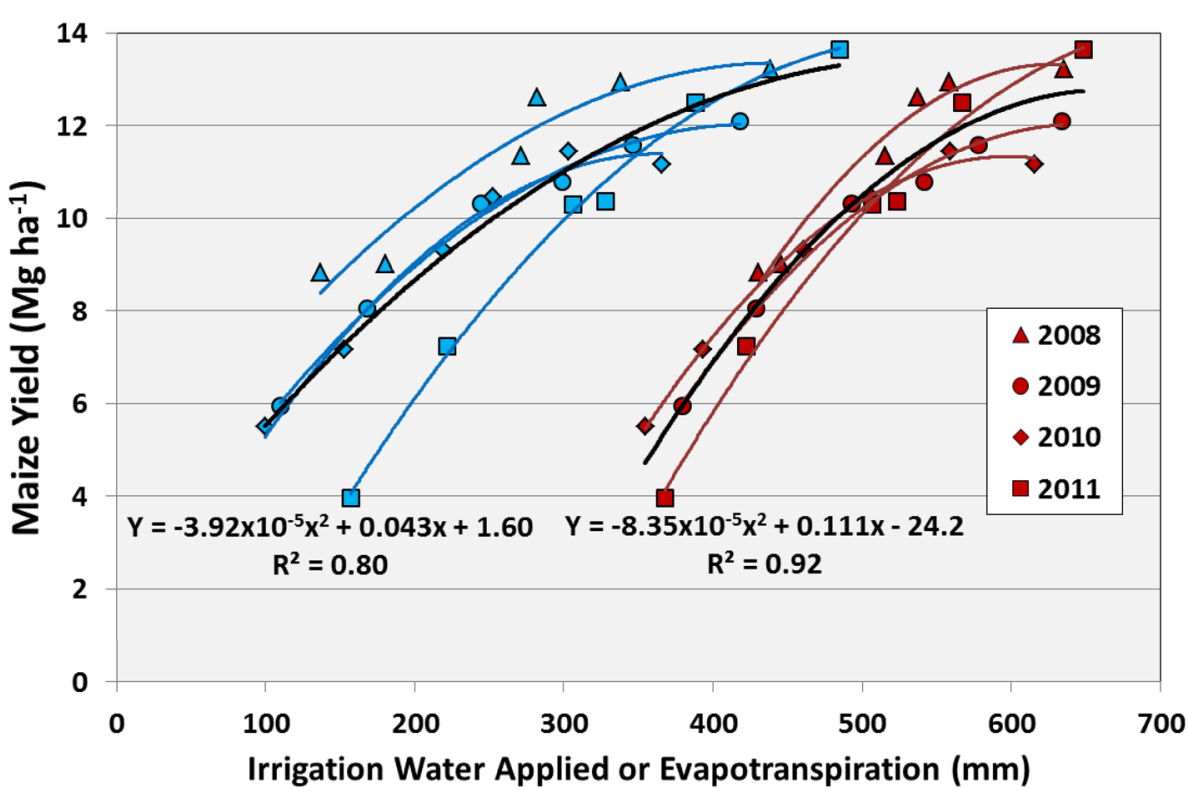




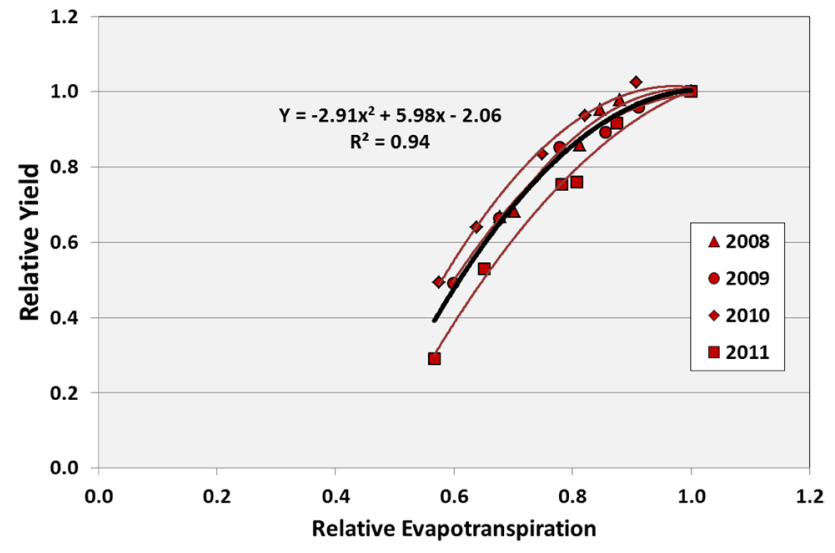

Fig. 8 LIRF 2008-2011 Maize normalized crop water production functions. Narrow (colored) lines represent the 2nd degree polynomial best fit for each year's data. Thick (black) line and equation is the best fit 2 nd degree polynomial for the combined data

deficits than with large deficits. Extrapolating the combined data curve to the $x$-axis indicates that about $275 \mathrm{~mm}$ of ETc is required to produce the first unit of yield.

The left set of curves (Fig. 7) represents the irrigation water production function, IWPF. These curves are shifted to the left relative to the WPFs due to the contribution of precipitation to evapotranspiration. Annual IWPF curves are less consistent than WPF curves due primarily to interannual variation in precipitation. The IWPF curves have lower slopes than the WPF curves because, at high irrigation levels, a portion of the applied water is lost to deep percolation (2008) or is left in the soil at the end of the season; and because, under deficit irrigation, a portion of water used for ETc is taken from soil water storage. The curves extrapolate to an intercept near zero, which implies that rain-fed (non-irrigated) maize production in the region would provide little to no yields. This is corroborated by the absence of rain-fed maize production in the area. Note that these IWPF curves were developed under precisely scheduled drip irrigation with high irrigation efficiency. Less efficient irrigation methods would require larger irrigation applications to meet full crop water requirements and result in IWPFs with lower slopes near full irrigation.

Several authors have suggested that WPFs can be normalized relative to the maximum yield and maximum ETc (Doorenbos and Kasam 1986). This normalization could compensate among years and locations with varying ETr and yield potential. Figure 8 shows the normalized yield vs ETc data and the WPF equation for the combined normalized datasets. Normalization for this dataset improves the relationship slightly, but would have larger effect on more disparate data.

Crop water productivity, CWP, (sometimes referred to as crop water use efficiency, WUE), represents the ability

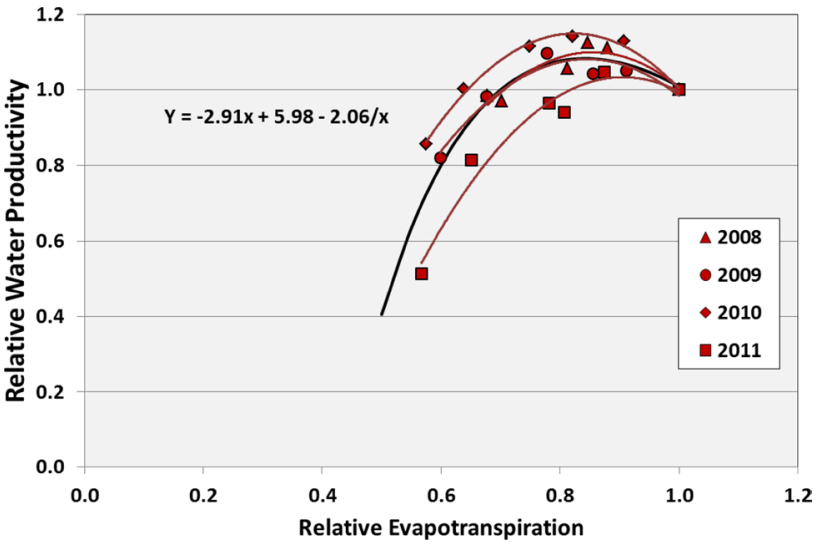

Fig. 9 LIRF 2008-2011 Maize normalized crop water productivity vs ETc. Narrow (colored) lines are 2nd degree polynomial best fit lines to each year's data. The thick (black) line is the algebraic conversion of the equation in Fig. 8

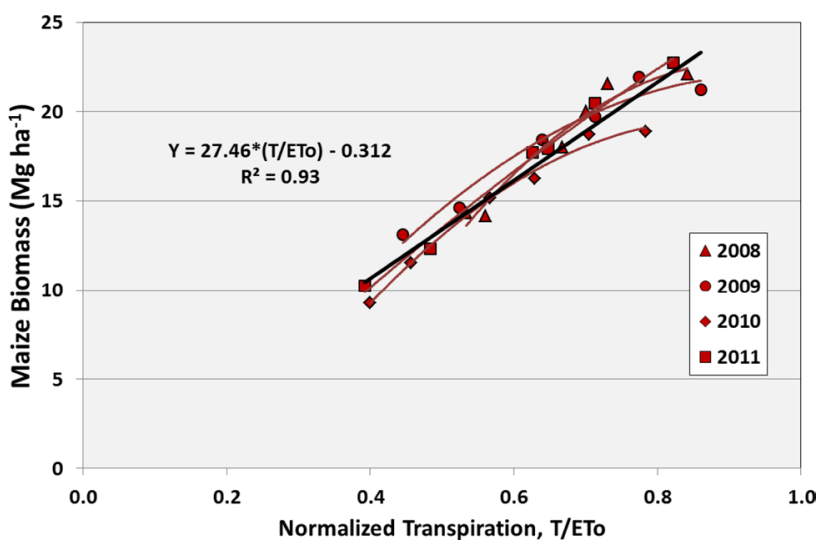

Fig. 10 LIRF 2008-2011 Maize biomass vs normalized cumulative transpiration between emergence and maturity (R6). Narrow (colored) lines are 2nd degree polynomial curves fit to each year's data. Thick (black) line and the equation are for a linear best fit line for the combined data

of a plant to convert ETc to yield. Crop water productivity, the production per unit of water consumed, in this trial was $2.0 \mathrm{~kg} \mathrm{~m}^{-3}$ of ETc at maximum ETc. The water productivity of the irrigation water applied was about $3 \mathrm{~kg} \mathrm{~m}^{-3}$ due mainly to the precipitation contribution to ETc. Figure 9 shows the normalized yield and ETc data converted to CWP and plotted vs relative ETc. These data indicate that, for this location, maize variety, and these management practices, CWP between $70 \%$ and $100 \%$ of ETc slightly exceeded the CWP at maximum ETc. At relative ETc below $70 \%$, CWP decreased rapidly. The maximum predicted relative CWP is about 1.08 at $85 \%$ relative ETc. This maximum CWP is likely biased upward by the 2010 data in which late stress resulted in $\mathrm{T} 2$ yield exceeding $\mathrm{T} 1$ yield, 
but all years show that CWP is fairly constant for relative ETc values above 0.7 .

Many water productivity researchers have proposed that biomass production is proportional to transpiration (Briggs and Shantz 1913; de Wit 1958; Stewart et al. 1977; Tanner and Sinclair 1983; Sinclair et al. 1984; Hanks 1983; Steduto et al. 2007). De Wit originally proposed that biomass yield, $Y$, is proportional to transpiration, $T$, normalized for evaporative demand, $E_{\mathrm{o}}$ :

$Y=m T / E_{0}$,

where $m$ is a crop-dependent coefficient of proportionality. This hypothesis is based on assumed fixed relationships between plant transpiration, $\mathrm{CO}_{2}$ photosynthetically assimilated by the crop, and biomass production. Figure 10 shows the LIRF above ground biomass vs the cumulative transpiration (water balance ETc minus estimated soil evaporation) divided by cumulative grass reference ETo for approximately 130 days between crop emergence and physiological maturity. Although the annual relationships are slightly curvilinear, a squared term does not significantly improve the regression and the shown linear relationship fits the combined data well. The small intercept is not significantly different from zero. These data support the concept that biomass production is proportional to transpiration with $4.3 \mathrm{~kg}$ of biomass produced for each cubic meter of transpiration. The slight curvilinear trend shown by these data indicates that the marginal rate of biomass production might decrease slightly with increasing transpiration.

The main differences between the curves in Fig. 10 and those in Fig. 8 are that the ETc values include the complete season from planting to senescence and include evaporation losses, both of which increase ETc and shift the curves to the right; and the dependent variable in Fig. 8 is relative grain yield, which is related to above ground biomass in Fig. 10 by the harvest index. Although the range of HI values was small, the relationship tended to be curvilinear downward (Fig. 6) resulting in greater curvilinearity for the grain yield vs ETc curves than for the biomass vs T curves.

\section{Discussion}

Table 1 summarizes results of ten recent studies of maize water productivity in the US Great Plains. All were field studies designed to apply treatments of adequate irrigation water to meet full ETc requirements and reduced amounts of water to induce crop stress. Irrigation water was applied by sprinklers except for the Payero et al. (2008) and Spurgeon and Yonts (2013) studies which used subsurface drip irrigation. All studies estimated ETc by water balance and all except Irmak (2015) assumed that deep percolation and runoff did not occur $(\mathrm{ETc}=$ irrigation + precipitation-change of soil water storage), and thus would have overestimated ETc if these losses occurred.

The studies are ordered in Table 1 by location from south to north. The ETc values of the highest irrigation treatment varied from $840 \mathrm{~mm}$ at Bushland, TX to $530 \mathrm{~mm}$ at Michell, NE. The variation is related to the declining trend in climatic evaporative demand (reference ET) and season length from south to north. Maximum grain yields vary between 12 and $15 \mathrm{Mg} \mathrm{ha}^{-1}$ and always occurred at or near maximum ETc. Yield trends with season length (longer season $=$ higher potential yield) and year (later studies $=$ more productive varieties) are not evident among these studies. All authors fit a linear relationship to the yield vs ETc data. Studies with sufficient range of yields and ETc projected positive ETc intercepts of $110-400 \mathrm{~mm}$, which is equivalent to the ETc required to produce the first unit of grain yield. The remaining studies had small yield ranges across the irrigation treatments. The minimum ETc to produce grain tended to vary with the maximum ETc, as both would be related to the evaporative demand. The maximum CWP values varied from 1.4 to $2.4 \mathrm{~kg} \mathrm{~m}^{-3}$ and always occurred at or near maximum ETc. Low values resulted from relatively low yield or high ETc. For studies that measured harvest index for the various water stress treatments, HI generally decreased with decreasing ETc (increasing stress).

Results of the current study are listed at the bottom of the table for comparison. The Greeley location has a shorter growing season and less precipitation than all except the Mitchell site. The seasonal reference ET at Greeley is less than the Texas and Kansas locations, and similar to the Nebraska locations.

Many past studies, like those in Table 1, have derived linear WPFs with a positive ETc intercept (Stewart et al. 1977; Hanks 1983; Doorenbos and Kassam 1986; Zwart and Bastinaanssen 2004). A commonly used WPF relationship is that of Doorenbos and Kassam (1986) who proposed that WPFs are linear and can be normalized relative to maximum $\mathrm{ETc}, \mathrm{ETc}_{\mathrm{M}}$, and maximum yield, $Y_{\mathrm{M}}$ :

$$
\left(1-Y \mathrm{a} / Y_{\mathrm{M}}\right)=k_{y}\left(1-\mathrm{ETa} / \mathrm{ETc}_{\mathrm{M}}\right),
$$

where $Y \mathrm{a}$ is harvested yield at a ETc value, ETa, and $k_{\mathrm{y}}$ is a yield response factor dependent on crop, climate, and management. Our WPF data are plotted in this form in Fig. 8 in which $Y_{\mathrm{M}}$ and $\mathrm{ETc}_{\mathrm{M}}$ are the grain yield and ETc values for treatment $\mathrm{T} 1$, respectively. The yield response factor (derivative) of the curve shown in Fig. 8 varies from 0.16 at $\mathrm{ETa} / \mathrm{ETc}_{\mathrm{M}}=1.0$ to 2.5 at $\mathrm{ETa} / \mathrm{ETc}_{\mathrm{M}}=0.6$. If a straight line is fit to the data, the slope is 1.36 , which is similar to the $k_{\mathrm{y}}$ value of 1.25 suggested by Doorenbos and Kassam (1986). 
Why do these data project a curvilinear WPF while most previous studies project a linear relationship? In many previous studies, the WPF data are sufficiently scattered that it is not possible to discern a relationship more complex than a straight line. These data exhibit a high coefficient of determination $\left(R^{2}\right)$, consistency among years, and significant curvilinearity. A curvilinear WPF would be expected if:

- Evaporation loss decreases with water deficits that limit transpiration. If reduced transpiration is created by fewer irrigations and less time with a wet surface soil, evaporation would be expected to decrease as water deficits limit transpiration. It is difficult to measure evaporation separately from transpiration to verify this relationship.

- HI decreases either for high deficits or at maximum ETc. This and several previous studies show a decline in HI with high deficits. Maximum ETc conditions could result in excessive vegetative growth and reduced HI. The HI vs ETc relationship depends on the timing of the water stress. Stress at critical periods would be expected to decrease yield and HI; reduced ETc at non-critical periods might increase HI by reducing vegetative biomass without equivalently reducing yield.

- Other non-water factors limit productivity under high water stress or near maximum production. It is likely that under some conditions, water stress makes plants more vulnerable to other stresses that may exacerbate yield losses, such as insect damage or competition from weeds, although we attempted to avoid these conditions in this study.

- The marginal rate of biomass production decreases near full transpiration. In this study, the biomass vs transpiration relationship appeared to have a small amount of curvilinearity.

The primary source for the curvilinearity of these WPFs is because yield declined less than ETc between treatments $\mathrm{T} 1$ and T2. Mean yields declined 5\% and were not significantly different between the two treatments in any year; while the ETc declined between 56 and $81 \mathrm{~mm}$ each year and an average of $11 \%$. These yield and ETc declines were not predicted by Ks in 2008, 2009, or 2011 when SWD did not exceed RAW at any time for either treatment. In 2010 when SWD exceeded RAW in the late season for both treatments, the difference between Ks values was small. These results indicate that moderate SWDs impact both ETc and yield, even when SWD $<$ RAW (i.e., Eq. 3 does not adequately predict impacts of moderate deficits), and that moderate deficits reduce ETc more than yield.

Because the slope of the WPF represents the marginal productivity of an additional amount of ETc at any ETc deficit level, the shape of the WPF is important for irrigation management decisions. If the WPF is curvilinear (concave downward) as derived in this study, the marginal productivity decreases with each additional unit of water supplied so that once a sufficient level of ETc is reached that yield is produced, and additional water should be spread evenly across a cropped area to generate the maximum yield. However, if the WPF is linear and water supply is limited, marginal productivity is constant and there is no disadvantage to concentrating additional supplies on a portion of the cropped area until the maximum ETc is reached.

Water production functions provide the information needed to maximize the benefits to irrigation under waterlimited conditions. However, their correct use depends on how water and benefits are counted. For an irrigation farmer whose only concern is the current cost or the availability of irrigation water, productivity relative to irrigation water applied is the important criteria. For a watershed or groundwater management region in which only ETc removes water from the watershed and return flows are effectively reused, productivity relative to ETc is important.

For the presented data, based on $220 \mathrm{~mm}$ of seasonal precipitation and highly efficient drip irrigation, a grower would lose only about $11 \%$ of yield by reducing irrigation by $25 \%$ (Fig. 7). The grower could achieve a $25 \%$ irrigation volume savings either through deficit irrigation by $25 \%$ or by reducing the area irrigated by $25 \%$. Although an economic analysis of production costs and yield value would be required to determine the best strategy to maximize net income, a decision based on irrigation volume might be to deficit irrigate his entire crop. The increase in CWP with deficit irrigation is greater with higher precipitation and stored soil water (illustrated by the IWPF curves in Fig. 7 shifting to the left) and with less efficient irrigation. With inefficient irrigation, the CWP based on irrigation amount is low near full irrigation but increases with deficit irrigation since irrigation efficiency and beneficial use of precipitation increases with deficit irrigation.

However, for situations in which the limitation is on consumed water or ETc, these data indicate that a $25 \%$ reduction in ETc would result in $25 \%$ reduction in yield. Under this condition, although the grower could reduce ETc either by deficit irrigation or by reducing planted area, deficit irrigation will seldom be the best economic choice since the yield loss would be the same for either option, but the cost of production would be reduced by cropping less land. As deficits exceed $25 \%$ and yields decline more rapidly than saved water (i.e., CWP declines), the economic disadvantage of deficit irrigation increases further. Linear WPF relationships represented by Eq. 5 with positive ETc intercepts result in a continuously decreasing CWP with reduced ETc such that full irrigation of reduced area will always be the most economical choice. 
In these trials, deficit irrigation was carefully scheduled (except for the late stress in 2010) to minimize the impact on yield, and drip irrigation reduced soil evaporation losses compared to sprinkler or furrow irrigation. Thus, they should represent an upper envelope of water productivity for our conditions and the variety used. Lower yields may result from high stress during critical growth stages or uneven stress. Ongoing research at LIRF is studying the impact of stress timing on yield and the ability of maize to acclimatize to stress.

The presented results may overestimate long-term yield expectations with deficit irrigation. With deficit irrigation, soil variability may have a larger impact on water availability and yield, unless management is adapted to localized conditions as with site-specific variable rate water application. Stressed maize is more susceptible to crop damage by mites and root insects. Stressed maize also has a tendency to have weaker stalks that are more susceptible to "blowdown" and lodging, making it more difficult to harvest. Although these problems can be reduced by management and genetic improvements, water-stressed maize will likely have increased risk of unanticipated yield losses.

Water production functions will likely change with time. Genetic improvements in maize varieties have resulted in an average 1 to $2 \%$ annual increase in maize yields with little or no increase in water use (Irmak and Sharma 2015). Thus, yields with newer varieties would be expected to have higher water productivity. The variety used in this trial was released in 2006. Current varieties used at the site yield 10 to $15 \%$ higher than those reported here, with no increase in ETc.

It is important when measuring water productivity to accurately estimate ETc. Because WPFs based on irrigation application depend on local conditions (precipitation amount and irrigation efficiency), it is difficult to use WPFs based on irrigation application for conditions other than those under which the measurements were made. However, WPFs based on ETc can be adapted to other conditions through adjustment for precipitation amount, irrigation efficiency, and evaporative demand. The seasonal ETc can be estimated by water balance when irrigation and precipitation are precisely measured and deep percolation and runoff losses are minimized.

\section{Conclusion}

Maize water production functions developed in a 4-year field trial in the US Central High Plains were curvilinear with $2.0 \mathrm{~kg} \mathrm{~m}^{-3}$ water productivity at maximum ETc. The functions show decreasing yield with decreasing ETc, but relatively constant crop water productivity up to $25 \%$ ETc reduction. Beyond 25\% ETc reduction, yields declined rapidly and no grain yield was produced at approximately $40 \%$ of full ETc. Although deficit irrigation may result in increased irrigation water productivity, reduction in irrigated area will nearly always provide higher net economic returns if water consumption is limited. However, after crops are planted and most production costs are expended, a curvilinear WPF indicates that remaining water supply should be spread evenly among the cropped area.

Open Access This article is distributed under the terms of the Creative Commons Attribution 4.0 International License (http:// creativecommons.org/licenses/by/4.0/), which permits unrestricted use, distribution, and reproduction in any medium, provided you give appropriate credit to the original author(s) and the source, provide a link to the Creative Commons license, and indicate if changes were made.

\section{References}

Abendroth LJ, Elmore RW, Boyer MJ, Marlay SK (2011) Corn Growth and Development. PMR 1009. Iowa State Univ. Extension, Ames

Allen RG, Pereira LS (2009) Estimating crop coefficients from fraction of ground cover and height. Irrig Sci 28:17-34

Allen RG, Pereira LS, Raes D, Smith M (1998) Crop evapotranspiration: guidelines for computing crop water requirements. FAO Irrigation and Drainage paper \# 56. FAO, Rome

Allen RG, Wright JL, Pruitt WO, Pereira LS, Jensen ME (2007) Water Requirements. Ch 8 in Hoffman GJ, Evans RG, Jensen ME, Martin DL, Elliott RL (eds) Design and operation of farm irrigation systems, 2nd edn. ASABE, St. Joseph

ASCE-EWRI (2005) The ASCE standardized reference evapotranspiration equation. Am Soc Civil Engr, Reston

Briggs IJ, Shantz HL (1913) The water requirement of plants: I. Investigation in the Great Plains in 1910 and 1911. USDA Bur Plant Ind Bull

Çakir R (2004) Effect of water stress at different development stages on vegetative and reproductive growth of corn. Field Crops Res 89:1-16

de Wit CT (1958) Transpiration and crop yield. Versl. Landbouwkd. Donderzock. No. 64.6. Inst. Of Biol. And Chem. Res. On Field Crops and Herbage. Wageningen, The Netherlands

Djaman K, Irmak S, Rathje WR, Martin DL, Eisenhauer DE (2013) Maize evapotranspiration, yield production functions, biomass, grain yield, harvest index, and yield response factors under full and limited irrigation. Trans ASABE 56(2):373-393

Doorenbos J, Kassam AH (1986) Yield response to water. FAO irrigation and drainage paper \#33. FAO, Rome

Hanks RJ (1983) Yield and water use relationships: an overview. In: Taylor HM, Jordan WR, Sinclair TR (eds) Limitations to efficient water use in crop production. ASA, Madison, pp 1-27

Howell TA, Copeland KS, Schneider AD, Dusek DA (1989) Sprinkler irrigation management for corn-southern great plains. Trans ASABE 32(1):147-155

Irmak S (2015) Interannual variation in long-term center pivot-irrigated maize evapotranspiration and various water productivity response indices. I: Grain yield, actual and basal evapotranspiration, irrigation-yield production functions, evapotranspirationyield production functions, and yield response factors. J Irrig Drain Eng. doi:10.1061/(ASCE)IR.1943-4774.0000825

Irmak S, Sharma V (2015) Large-scale and long-term trends and magnitudes in irrigated and rainfed maize and soybean water 
productivity: grain yield and evapotranspiration frequency, crop water use efficiency, and production functions. Trans ASABE 58(1):103-120. doi:10.13031/trans/58.10784

Jensen ME, Allen RG (2016) Evaporation, evapotranspiration, and irrigation water requirements. ASCE Manual of Practice 70, 2nd edn. American Society of Civil Engineers, Reston, VA

Klocke NL, Currie RS, Tomsicek DJ, Koehn J (2011) Corn yield response to deficit irrigation. Trans ASABE 54(3):931-940

Lamm FR, Aiken RM, Abou Kheira AA (2009) Corn yield and water use characteristics as affected by tillage, plant density, and irrigation. Trans ASABE 52(1):133-143

Payero JO, Tarkalson DD, Irmak S, Davison D, Petersen JL (2008) Effect of irrigation amounts applied with subsurface drip irrigation on corn evapotranspiration, yield, water use efficiency, and dry matter production in a semiarid climate. Agric Water Manag 95:895-908

PRISM Climate Group (2015) 30 year normals. http://prism.nacse. org/normals/. Accessed 1 April 2017

Salter PJ, Goode JE (1967) Crop response to water at different stages of growth. Commonwealth Agricultural Bureau. Bucks. Farnham Royal, England

Schlegel AJ, Assefa Y, O'Brien D, Lamm FR, Haag LA, Stone LR (2016) Comparison of corn, grain sorghum, soybean, and sunflower under limited irrigation. Agron J 108(2):670-679

Schneekloth JP, Klocke NL, Hergert GW, Martin DL, Clark RT (1991) Crop rotation with full and limited irrigation and dryland management. Trans ASABE 34(6):2372-2380

Schneider AD and Howell TA (1998) LEPA and spray irrigation of corn—Southern High Plains. Trans ASABE 41(5):1391-1396

Sinclair TR, Tanner CB, Bennett JM (1984) Water-use efficiency in crop production. Bioscience 34:36-40
Spurgeon WE, Yonts CD (2013) Water productivity of corn and dry bean rotation on very fine sandy loam soil in western Nebraska. Appl Eng Agric 29(6):885-892

Steduto P, Hsiao TD, Fereres E (2007) On the conservative behavior of biomass water productivity. Irrig Sci 25:189-207

Stewart JI, Hagen RM, Pruitt WO, Hanks RJ, Riley JP, Danielson RE, Franklein WT, Jackson EB (1977) Optimizing crop production through control of water and salinity levels in the Soil. Pub No. PRWG 151-1. Utah Water Res. Lab., Utah State Univ., Logan.

Tanner CB, Sinclair TR (1983) Efficient water use in crop production: research or re-search. In: Taylor HM, Jordan WR, Sinclair TR (eds) Limitations to efficient water use in crop production. ASA, Madison, pp 1-27

Trout TJ, Bausch WC (2017) USDA-ARS Colorado maize water productivity data set. Irrig Sci. doi:10.1007/s00271-017-0537-9

USDA-NASS (2015) USDA-National Agricultural Statistics Service. http://www.nass.usda.gov/Statistics_by_State/Colorado/. Accessed 1 April 2017

USDA-NRCS (2015) USDA-NRCS WEB soil survey. http://websoilsurvey.nrcs.usda.gov/app/HomePage.htm. Accessed 1 April 2017

Zang H (2003) Improving water productivity through deficit irrigation: examples from Syria, the North China Plain and Oregon. Ch 19 in Kinje JW. In: Barker R, Molden D (eds) Water productivity in agriculture: limits and opportunities for improvement. CABI Publishing, Wallingford

Zwart SJ, Bastiaanssen WGM (2004) Review of measured crop water productivity values for irrigated wheat, rice, cotton and maize. Ag Wat Man 69:115-133 